\title{
Newcomer to the Academic Scene: The Two-Year College Library/Learning Center
}

\begin{abstract}
O NE LARGE COMPONENT of the academic library scene today, the two-year college library or learning center, is a development of the twentieth century. All contributions made by these libraries are recent. Even though a few junior colleges can trace historical roots and antecedent institutions back beyond 1876, more two-year colleges have been established during the past decade than can show fifty or more years of existence. Their libraries also have a short history. Nonetheless, today two-year colleges constitute more than one-third of all institutions of higher education and enroll almost a proportionate number of college students; their libraries and staffs have made real contributions as well. A review of their development, with attention to the provision for library and learning resources, is pertinent to the centennial of the American Library Association.
\end{abstract}

The term "two-year college" is applicable equally to junior colleges, technical institutes, community colleges, and to some branches of senior colleges and universities. Colleges admitting students as juniors for two years of baccalaureate work in Florida, Texas, and some other states are considered upper divi- sion colleges rather than two-year colleges.

As two-year colleges first existed and as this term is used today, a junior college is an academic institution whose curriculum parallels the freshman and sophomore years of a traditional baccalaureate program, enabling the graduate to transfer later to a senior college or university as a junior. This term continues to be appropriate to most private and some public institutions as well as to some two-year branches, but, except in an historical and sometimes legal sense, it no longer applies to most twoyear colleges.

Technical institutes provide vocational and technical training programs for adults; such programs may include academic emphases which might be transferable.

The most complex category is the "community college." Community colleges, usually publicly supported, provide a comprehensive curriculum with both academic programs and technical programs, together with developmental programs to remedy previous educational deficiencies and continuing education programs to meet informational, avocational, or vocational training and re- 
training needs of the local community. Most community colleges offer opportunities at night as well as during day hours to part-time students otherwise in full-time employment.

The dynamics of the two-year college are reflected in the changing philosophy of community college librarians who now are concerned with a full range of learning resources services rather than being limited to traditional library services only. As has been pointed out by Gary Peterson, the resulting "learning center" is an enhancement of resources and services, including all previous library functions, to meet needs of the learner. ${ }^{1}$ It is not an involuntary merger of library and audiovisual services with instructional development and other nontraditional services.

Some four-year colleges have already made a similar move in the direction of a full learning resources program, but the contrast between the patterns of services in two-year and four-year academic institutions is nowhere more apparent than in the differences between the recent "Standards for College Libraries" (1975) and the "Guidelines for Twoyear College Learning Resources Programs" (1972). ${ }^{2}$

In this review "library" always indicates the traditional pattern of printrelated library services and "learning resources program" the expanded organizational pattern and services described in the Guidelines and practiced in most community colleges.

The Early Years of THE Junior College to 1945

William Rainey Harper, President of the University of Chicago at the turn of the century, is generally recognized as the man most responsible for beginning the junior college movement. Harper, along with Henry P. Tappan of the University of Michigan, William W. Folwell of the University of Minnesota, and others envisioned such two-year in- stitutions as adjuncts to secondary education so that upper division and graduate education could become the sole scope of the university. These men would have heartily endorsed the establishment of upper division universities (such as Florida Atlantic University and the University of Texas at Dallas), but they might have been bewildered by the comprehensive community college of today that was built upon their ideas.

Private junior colleges outnumbered the publicly supported institutions until World War II. Many of these institutions started as academies, finishing schools, institutes, and seminaries which added two years of academic work to the courses already offered. As the junior college idea was discussed, they adopted the new name for their programs. Later some dropped the preparatory years, simply becoming junior colleges.

There were other junior colleges, originally four-year institutions, which became two-year colleges by dropping the upper division. One example is Decatur Baptist College. It was founded as a four-year college under another name. Under a subsequent reorganization it became an institution that was long recognized as the oldest private junior college, until its merger into Dallas Baptist College a few years ago.

All private institutions were not the result of expansion or contraction of offerings. Some were organized as junior colleges, as was true in the founding of Sarah Lawrence College. ${ }^{3}$

Joliet Junior College, Joliet, Illinois, has the distinction of being the oldest public junior college from its establishment in 1901. It was founded under Harper's influence as an upward extension of the local high school. There are public institutions today dating their founding earlier than Joliet, but all these (such as Blinn College in Brenham, Texas, and St. Philip's College in San Antonio, Texas) began as private 
institutions which were later transferred to public control.

While the junior college library is the main focus of this paper, some overview of the junior college movement is necessary for an understanding of the development of library services. Genung and Wallace have pointed out a number of uncertainties which were of great importance in shaping library services. ${ }^{4}$ These problems had to be resolved before developing appropriate library services:

1. Was the junior college to be a part of higher education (with libraries corresponding to those in senior colleges), or was it to be part of secondary education (with libraries at the level of those in the high school)?

2. Should vocational and technical education be included in the two-year college?

3. How should the junior college respond to community needs and to the equally pressing demands of the four-year institution for articulation solely by copying baccalaureate requirements?

4. How can adequate state support and legislation for public community colleges be obtained in order to promote their development?

In general, some of these problems have now been resolved. The two-year college today is definitely part of the academic scene. Technical and vocational education has been provided in the curriculum of the comprehensive community colleges and the technical institutes, and these accredited institutions can be and are members of the regional associations. State legislation providing for the organization, functioning, and support of two-year colleges and for the creation of state systems has been passed in most states.

Problems of articulation still cause difficulties with some senior colleges and universities because of seemingly capri- cious curriculum requirements unique to these individual institutions. Other institutions, however, even compete for the vocational and technical graduate through adapting their degree requirements to meet the needs of such transfer students.

The resolution of these problems occupied much of the time of the officials of the American Association of Junior Colleges, of state associations, and of the leadership in the junior college movement. By 1945 it was apparent to most observers that a uniquely American institution had developed as a part of higher education and that such twoyear colleges had earned a permanent place.

\section{LIBRARIES BEFORE 1945}

Librarianship in the junior colleges during these formative years was largely reflective of the stage of development in the parent institutions. Where the public junior colleges were upward extensions of the high school and were controlled by the local school board and the school superintendent, the high school library, if indeed there was one, provided library service to the junior college students.

Such collections were small, but it must be remembered that the American Council on Education in 1926 required a library of 8,000 volumes only for an accredited four-year college. ${ }^{5}$ The North Central Association at that same time required only 3,000 volumes for an accredited junior college. ${ }^{6}$ The best junior college libraries before 1945 were frequently in financially well-endowed private institutions where preparation of their students for transfer to a baccalaureate institution was the main objective. Instructional methods, with emphasis upon reading and using libraries in the preparation of research papers, made a climate more favorable to library development than in the public institutions. 
Professional support to library aspirations was also a recognizable aspect in development of library services in the two-year institutions. In 1929 the Junior College Round Table was organized by the American Library Association to provide opportunities for junior college librarians to share information about the needs of their institutions. This was of particular value because there was then no other source of training for the needs of the two-year institution; and most librarians, in the public junior colleges at least, came from previous positions in high schools.

The round table and its successor, the Junior College Libraries Section of the Association of College and Research Libraries, concentrated on the development of a viable set of standards to encourage library service. The 1930 standards approved at the Los Angeles Conference were quite modest but were beyond all but a few libraries then: A book collection of 10,000 volumes for the first 500 students, an annual expenditure of $\$ 5$ per student for materials, and a staff of at least two professional librarians. ${ }^{7}$

The breakthrough in development of junior college libraries came from the action in 1938 of the Carnegie Corporation in making a series of ninety-two grants to junior college libraries. Through this move the need for financial support of junior college libraries was dramatized, and local support was encouraged. The librarians themselves were thus given assurance that they were not alone in seeking to develop their libraries and began to experiment with new energy. Perhaps the best known is the Stephens College experiment, but other innovations were attempted at the Menlo School and Junior College as well as at other institutions. ${ }^{8} \mathrm{~A}$ by-product of the Carnegie grants was the increase in publications concerning the junior college library.

One grant made by the Carnegie Corporation was to Stephens College, Co- lumbia, Missouri, a private junior college for women whose president, James M. Woods, was preparing for a change which has had a continuing effect on the two-year college. President Wood employed B. Lamar Johnson as librarian and dean of instruction with the task of making the library a central participant in the instructional program of the college. For the first time the library was allowed to play a vital role in the learning process, and the librarian was recognized as an administrator.

Johnson described the results in his book, Vitalizing a College Library, and its impact continues as a challenge to junior college administrators and librarians alike. ${ }^{9}$ Johnson, himself, has played a significant role, making a lasting contribution to junior college librarianship not only while he was at Stephens but also later as a professor of junior college administration in California. As precursor and example for the learning resources administrator of today as well as facilitator of changes in the climate of libraries, Johnson has had no peer.

Johnson was not the only librarian who made a significant contribution to the two-year college library. Several others also deserve recognition: Ermine Stone, librarian at Sarah Lawrence College when it was a junior college, by her research and writing and her work among junior college librarians in the American Library Association provided valuable assistance and leadership when they were most needed. Lola Rivers Thompson, at John Tarleton College, created a good example of library service in this agricultural junior college which challenged Texas librarians. The compilers of the early lists of books for use in developing junior college libraries are also due mention: Edna A. Hester, ${ }^{10}$ and Foster E. Mohrhardt. ${ }^{11}$

At the close of World War II the typical junior college library showed little change from the earlier descriptions 
by Stone, Adams, or Eells. ${ }^{12}$ Few had more than 10,000 books or more than one librarian. The collections were, however, generally quite selective because emphasis on numbers had not led to acceptance of quantities of inappropriate gifts. Library services were geared to capable students who were attending because of financial limitations rather than because they were less talented academically than in the larger institutions.

Very few of the junior college libraries were open at night except those serving dormitory populations, usually in the private institutions. Some few, like Stephens, had collections of phonograph records and art prints. Most, however, not only had no audiovisual services as part of the library, but no one expected that they should be provided elsewhere on the junior college campus.

\section{The Junion College Movement 1945-1960}

The most significant change in the role of the two-year college came immediately after World War II when increased emphasis was placed on technical and vocational education. The inclusion of such courses in the instructional programs of junior colleges was not new, but there was a new recognition of such programs as a major function of the two-year college.

The expansion of technical education came with such rapidity that by 1950 a new term "community college" came into general usage to describe the difference from the traditional junior college. The application of the term was fixed by the use made by Jesse Parker Bogue, Executive Secretary of the American Association of Junior Colleges, to describe the expanding role and the subsequent acceptance of this idea. ${ }^{13}$ The idea was not new and had been explored for a decade, following a significant study of terminal education begun in 1939 but not completed until 1942 after the nation was at war. ${ }^{14}$ The study was widely accepted by citizens' groups and incorporated into national planning for postwar needs.

After the war the returning veterans who came to the two-year colleges helped change the image of the typical student from one just out of high school to a married adult student continuing his or her education. Since then student bodies in two-year colleges have shown wide ranges of age and abilities not found before the war.

Needs of working veterans as well as favorable experiences during the war years in teaching specialized courses at night to meet wartime manpower needs caused most urban community colleges to develop parallel academic and technical programs to operate in the evenings. Classes were often taught by parttime instructors in the community as well as by regular contract faculty. The use of highly qualified professionals and skilled technicians as part-time instructors has made a valuable contribution to the educational programs. The provision made for adults to attend college courses for credit during night hours became a fixed part of the twoyear urban college during these years.

The period from 1945 to 1960 might well be characterized as a time of expansion, experimentation, and coping with new demands. The development of new technical programs, the determination of the relationship between general education and technical education as part of an associate degree, and the creation of new organizational and administrative patterns for the operation of the colleges consumed the time and interest of the faculties.

\section{The Libraries, 1945-1960}

The changing nature of the two-year public institution during these years is reflected in the attempts of the libraries to meet the new demands. The experience of San Antonio College reflects 
largely what happened in other institutions.

Until 1946 San Antonio College had been operated by a school district, but in that year the voters created a separate union district to operate two colleges. Because the public library was within two blocks of the campus, the public library absorbed most demands. The result was that the collection at the college contained only 8,000 volumes, the staff was a single professional librarian, and hours available were limited to thirty-six hours a week. In 1948 evening classes were begun on a regular basis, and the following year a student was employed to keep the library open for three hours four nights each week for circulation service and study. In 1950 a second librarian was employed to give professional assistance in the evening. In 1954 the first full-time clerk was added. By 1960 there were four professional and five paraprofessional staff members. The book collection had increased to 24,578 volumes, and the annual budget had grown from $\$ 5,934$ in 1946-47 to $\$ 57,135$ in $1960-61$. All library services were as complete at night as during day hours. More direct library instruction was given to adults in the evening than to daytime students because they recognized the need and requested it. The college moved to a new campus in 1951 with library quarters which were adequate for fifteen years of growth.

A number of outstanding two-year college libraries had developed in California, Illinois, Michigan, Florida, and Texas by 1960 . In these institutions there were librarians who were willing to use their talents to provide professional leadership in regional and state library associations. Nationally the private institutions provided more leaders in the Junior College Libraries Section than the public colleges because of provision for travel in their budgets.

Ruth E. Scarborough, Centenary Junior College, in Hackettstown, New Jer- sey, for example, was a major contributor to the work of the section, not only as chairman of the section but also as a leader in the struggle for acceptable standards. Other librarians who made valuable personal contributions in ALA during these years included Frances L. Meals, Lottie M. Skidmore, Thelma Taylor, Ira Peskin, Elizabeth Neal, and Orlin Spicer.

\section{Two-Year Colleges in the 1960s}

The 1960s were a period of unprecedented expansion for two-year colleges. In number they increased from 390 colleges in 1959 to 794 in 1969. Enrollments increased from 551,760 in 1959 to $2,051,493$ in $1969 .{ }^{15}$ The organization of public colleges in separate governmental districts, the beginnings of state systems and of state plans for two-year colleges, the creation of large urban multi-campus districts, and an emphasis on innovation best described by B. Lamar Johnson in Islands of Innovation Expanding 16 are but some of the developments during these years among two-year colleges.

The two-year colleges were not immune to campus unrest and student activism of the decade, but with some few exceptions, they were less affected than were the senior colleges and universities. What did affect them were the continued attendance of veterans of the various military involvements, the arrival of the postwar babies reaching age to enter college, and the increased numbers of first generation college students from minority and other groups which had not been traditional college students.

The public two-year colleges, at least, had always held the tradition of being open-door institutions. Most of them had made provision for remedial work, usually in mathematics (for students who did not have prerequisites for engineering in the high schools) and in English composition. The college students 
who were entering the freshman class in the 1960s often included those who were less proficient academically as well as adults returning to the classroom after long periods out of school. Use made of the G.E.D. and other equivalency examinations also pointed to need for the provision for remedial and developmental programs. Foundation courses to relieve academic and educational deficiencies in learning skills (such as reading and mathematics) and oral and written language skills as well as new preparatory courses in the sciences and social sciences became normal parts of the curriculum.

The acceptance of the challenge to meet the needs of a diversified and heterogeneous group of students created an interest in the psychology and application of learning principles among many faculty members by the 1970s. Restructuring traditional courses utilizing behavioral techniques, individualized instruction, and application of new technologies received much attention from the faculties. Experimentation in instructional techniques to meet student needs and provision for faculty development programs to make possible adjustments from traditional lecture methods became features of community college educational programs.

The major concerns of the two-year college today focus, as in the 1960s, on the continuing problems of articulation with senior colleges, the challenge of the nontraditional student, the continuous reappraisal of instruction in the attempt to meet the needs of the diversified student bodies, the openness to new technological developments in the classroom, the need for developing faculty sympathetic to the philosophies of the two-year institutions, the redefinition of institutional role in the changes that are occurring both internally and in the local communities, and the increasing economic pressures in meeting financial and physical needs of the colleges. ${ }^{17}$

\section{The Emergent Learning Resources Program}

The 1960 s were the years of change in the provision for services from the traditional print-oriented library services to a full learning resources program. In 1960 no one could have predicted the great change that would occur in a ten-year period because the pattern of junior college library service itself was just emerging. The publication in that year of "Standards for Junior College Libraries" by the Association of College and Research Libraries provides a convenient line of demarcation. ${ }^{18}$

The 1960 standards were a professional landmark. They provided for the first time a description of good library services in the two-year institution. There was a formula for the size of the book collection correlated with enrollment, with a minimum collection of 20,000 volumes for the first 500 students. There is no need to discuss these standards in detail because this has been done, ${ }^{19}$ but the extensive use made of them by two-year colleges and by the U.S. Office of Education in evaluating applications for grants confirmed both the soundness of the standards and their significance in improving services.

Initial negative reaction of administrators to the new standards was overcome through dialogue with librarians and the establishment of a joint committee between the American Library Association and the American Association of Junior Colleges as well as a recognition that the use of the term "standards" did not refer to the standards of the regional accrediting associations.

Another contribution of the Junior College Libraries Section came through the series of preconference institutes held from 1965 to 1972 . These meetings focused upon the problems, practices, and contributions of the two-year colleges and made it possible for administrators and librarians of new institu- 
tions to understand the challenges inherent in the role of the librarian. The recognition of the librarian as an administrator was greatly enhanced as a result of the professional concerns demonstrated in these meetings. The acceptance of faculty status for librarians was also reinforced.

The Junior College Libraries Section was involved in many productive activities during the 1960s. Among the projects was the bibliography compiled by James W. Pirie utilizing the holdings of three leading libraries. ${ }^{20}$ Two-year college librarians actively participated in the establishment of Choice. The J. Morris Jones/World Book Encyclopedia/ALA Goals Award was granted to the section in 1967 to support a Junior College Library Information Center at ALA Headquarters for one year in order to gather appropriate data and to answer inquiries and disseminate information about publications, policy statements, building programs, services, and all other types of needed information about junior and community colleges.

When Helen Wheeler surveyed a number of junior colleges in 1963, she found that the ALA Standards were already being utilized in most of the libraries, that only 35.8 percent contained a minimum of 20,000 volumes, that more than half of librarians responding did not believe that the materials needed were in the collection, and that more than half of the libraries had a separate library building. The trend to a learning resources program had already begun, with 37.8 percent of the colleges having already centralized these responsibilities. Only six out of 103 responding colleges met the requirements of the standards in terms of collection size, seating, and staff, and three of these did not receive 5 percent of the college budget. ${ }^{21}$ In contrast, by 1969 operating expenditures in two-year colleges for libraries represented a median of
6.1 percent, the median number of professional staff was 4.2 , and there were a total of $13,693,277$ volumes in the twoyear colleges (with a mean of 23,732)..$^{22}$ An increase of 67 percent in the book collection from a mean collection size of 14,201 in 1963 was no little accomplishment. ${ }^{23}$

The contribution of community college librarians to the provision for the education of library and media technical assistants was one of the significant contributions of the two-year colleges. In the judgment of community college librarians there was need for training of supportive staff for all types of libraries. As they were acquainted with other phases of technical training provided in the two-year programs with emphasis on skills, it was realistic for them to take the lead in such training. While some early programs were not well designed and were sometimes undertaken without regard to the job market, most met a valid need for trained supportive staff members, especially in school and special libraries. After a troubled start, the concept was adopted in the manpower policy of the American Library Association in 1970, and criteria for instructional programs were approved by the Library Education Division in $1969 .{ }^{24}$

By the end of the 1960 s librarians from two-year colleges were very active and were making personal and professional contributions to the activities of the American Library Association and the Association of College and Research Libraries as well as in the Association for Educational Communications and Technology (AECT). Not only were they serving in sectional offices and on sectional committees, but they were active, even chairing divisional and ALA committees and serving as officers or candidates for office. The contributions of Norman Tanis on the ACRL Committee on Standards while he was still 
a community college librarian are a case in point.

\section{The Current Decade}

In 1970 the American Association of Community and Junior Colleges received a grant from the W. K. Kellogg Foundation for a nationwide study of the community college to determine the direction in which it was headed and the changes needed to meet necessary objectives. The report of this study pointed to this decade as a period in which community colleges would consolidate their achievements and stabilize their operations. The study also underscored the role of the community college in meeting the needs of disadvantaged and minority groups.

Six trends were identified:

1. Need for more effective developmental education program offerings.

2. Expanded minority group enrollment which would require positive attempts to resolve imbalance of minority faculty members.

3. Institutional commitment to strengthened lifelong learning programs.

4. Improving articulation of career and transfer programs.

5. Systematic needs assessment and communication efforts to provide closer linkage with the community.

6. New organizational structures in the colleges. ${ }^{25}$

These trends, along with the current economic problems, remain a valid assessment.

Currently, the most insistent concern is that the pressures of inflation and budgetary reassessments will cripple the ability of community and junior colleges to meet educational needs. The best expression of this concern is in the resolution, titled "Doors to Educational Opportunity Must Be Kept Open," adopted at the 1976 convention of AACJC. ${ }^{26}$ A paraphrase of portions of this resolution could also reflect the concerns for the learning resources programs in two-year colleges as they will be affected by institutional budgets.

\section{Learning Resources Programs IN THE 1970 s}

The adoption of "Guidelines for Two-Year College Learning Resources Programs" in 1972 as the result of joint participation by the AACJC, AECT, and ALA (ACRL) demonstrated not only inter-associational cooperation, in itself a contribution, but was as well an assessment of the changes which had occurred in a single decade. ${ }^{27} \mathrm{~A}$ study of Texas community colleges to determine the extent that these guidelines reflected current practices made by Mary Nieball in 1975 found that with minor exceptions almost all were operating learning resources programs. ${ }^{28}$ The contrast with earlier conditions in the state (not one of the leaders in the transition) was further confirmed by the recent statistics issued by the Texas State Library in which only two public and three private junior colleges had less than the 20,000 volumes (suggested as a minimum collection in the 1960 standards), with one having 174,000 volumes and others having smaller but still effective collections. ${ }^{29}$

The community college library today (so ably described in structure and services by Fritz Veit), ${ }^{30}$ in spite of variations and differences between institutions, can be differentiated from other types of libraries in a number of ways which, though not in themselves necessarily unique, are in the amalgam different.

In the first place, there is found a commitment to direct involvement in instruction in programs for library/ media technicians and also in the bone and marrow of instructional development.

The learning resources program, in the second place, includes automatic 
utilization of information for learning in whatever format it can be foundprint, microprint, or audiovisual. Again, the learning resources program includes operation of instructional learning laboratories, language laboratories, distribution of equipment, operation of closed circuit television, as well as providing traditional study facilities.

Staff members in the learning resources program are directly involved in production of instructional learning packages on the community college campus. The administrative head, having had training in both traditional library and audiovisual services, is more often a dean or vice-president than in most four-year institutions. The professional staff usually includes a number of specialists in educational technology as well as of those with library school training.

Among the supportive staff will be large numbers of technicians with training not only as library or media technicians but also as television, graphics, electronics, and photographic technicians.
Finally, all traditional library services will be available in the two-year college learning resources program with their effectiveness enhanced by the availability of other informational sources.

Community and junior college librarians today have made contributions to librarianship deserving notice. Leadership, such as that Harriett Genung provided at Mt. San Antonio College in developing a model program for California and the nation to copy, always makes a significant contribution. A community college librarian, Louise Giles, has already served as president of the Association of College and Research Libraries. Perhaps in the next century one or more will even serve as president of the American Library Association. ${ }^{31}$ The learning resources programs and the libraries as they have developed are now supportive of institutional purposes and demonstrate all attributes of good library services, even providing services rarely found in other academic institutions.

\section{REFERENCES}

1. Gary T. Peterson, The Learning Center: A Sphere for Nontraditional Approaches to Education (Hamden, Conn.: Linnet Books, 1975), p.22-26.

2. Association of College and Research Libraries, "Standards for College Libraries," College \& Research Libraries News 36: 277-79, 290-301 (Oct. 1975); American Library Association (Association of College and Research Libraries), American Association of Community and Junior Colleges, and Association for Educational Communications and Technology, "Guidelines for Two-Year College Learning Resources Programs," College \& Research Libraries News 33:305-15 (Dec. 1972).

3. The history of the junior college movement is adequately traced in such books as Walter Crosby Eells, The Junior College (Boston: Houghton Mifflin, 1931); Tyrus Hillway, The American Two-Year College (New York: Harper, 1958); Jesse Parker Bogue, The Community College (New York: McGraw-Hill, 1950); James W.
Thornton, Jr., The Community Junior College, 2d ed. (New York: John Wiley, 1966); and Robert S. Palinchak, The Evolution of the Community College (Metuchen, N.J.: Scarecrow, 1973).

4. Harriett Genung and James O. Wallace, "The Emergence of the Community College Library," Advances in Librarianship 3:29-81 (1972).

5. E. B. Ratcliffe, Accredited Higher Institutions ([U.S. Bureau of Education, Bulletin no.10] Washington, D.C.: Govt. Print. Off., 1926), p.26; as cited in Eells, The Junior College, p.446.

6. Ibid., p.447.

7. E. M. Homer, "A Junior College Measuring Stick," ALA Bulletin 24:296-97 (1930).

8. Harlen Martin Adams, The Junior College Library Program: A Study of Library Services in Relation to Instructional Procedures (Chicago: American Library Assn. and Stanford Univ. Pr., 1940).

9. Byron Lamar Johnson, Vitalizing a College Library (Chicago: American Library Assn., 1939). 
10. Edna A. Hester, Books for Junior Colleges (Chicago: American Library Assn., 1931).

11. Foster E. Mohrhardt, A List of Books for Junior College Libraries (Chicago: American Library Assn., 1937).

12. Ermine Stone, The Junior College Library (Chicago: American Library Assn., 1932); Adams, The Junior College Library Program; and Eells, The Junior College, p.44372.

13. Bogue, The Community College.

14. See Walter Crosby Eells, Why Junior College Terminal Education ([Terminal Education Monograph, no.3] Washington, D.C.: American Association of Junior Colleges, 1941).

15. American Junior Colleges, 8th ed. (Washington, D.C.: American Council on Education, 1971), p.3.

16. Byron Lamar Johnson, Islands of Innovation Expanding: Changes in the Community College (Glencoe, Ill.: Glencoe Press, 1969).

17. James O. Wallace, "The Environment of the Two-Year College." Paper prepared for the ACRL Ad Hoc Subcommittee on Goals, Priorities, and Structures, 1975.

18. Association of College and Research Libraries, Committee on Standards, "Standards for Junior College Libraries," College \& Research Libraries 21:200-206 (May 1960).

19. James O. Wallace, "Two-Year College Library Standards," Library Trends 21:21932 (Oct. 1972).

20. James W. Pirie, Books for Junior College Libraries (Chicago: American Library Assn., 1969).

21. Helen Rippier Wheeler, The Community College Library: A Plan for Action (Hamden, Conn.: Shoe String Press, 1965), p.79-80, 99-133.

22. U.S. Office of Education, Library Statistics of Colleges and Universities, Fall 1969,
Analytic Report (Washington, D.C.: Govt. Print. Off., 1971), p.54-59.

23. U.S. Office of Education, Library Statistics of Colleges and Universities, 1963-64 Analytic Report (Washington, D.C.: Govt. Print. Off., 1968), p.28.

24. American Library Association, "Library Education and Manpower," American Libraries 1:341-44 (1970); American Library Association, Library Education Division, "Criteria for Programs to Prepare Library Technical Assistants," LED Newsletter, no. 68, p.7-16 (1969).

25. David S. Bushnell, Organizing for Change: New Priorities for Community Colleges (New York: McGraw-Hill, 1973); Edmund J. Glezer, Jr., Project Focus: A Forecast Study of Community Colleges (New York: McGraw-Hill, 1973).

26. "Doors to Educational Opportunity Must Be Kept Open," Community and Junior College Journal 47:3 (Sept. 1976).

27. American Library Association (Association of College and Research Libraries), American Association of Community and Junior Colleges, and Association for Educational Communications and Technology, "Guidelines for Two-Year College Learning Resources Programs."

28. Mary Louise Nieball, "A Comparative Analysis of Library-Learning Resources Programs in the Public Junior Colleges of Texas" (Ph.D. diss., Texas Woman's University, 1975).

29. Texas State Library, Library Development Division, Texas Public Library Statistics for 1975 (Austin, 1976), p.153-65.

30. Fritz Veit, The Community College Library (Westport, Conn.: Greenwood Press, 1975).

31. Frances Lander Spain became a community college librarian in Florida after having served as president of the American Library Association.

James $O$. Wallace is director of learning resources, San Antonio College, San Antonio, Texas. 